\title{
APPLICATION OF AHP TO DETERMINE CONSUMERS' PERCEPTIONS OF CSR STRATEGY FOR ORGANIZATIONS IN THE NIGERIAN GSM TELECOMMUNICATION INDUSTRY
}

\author{
Bolajoko Nkemdinim Dixon-Ogbechi* \\ Faculty of Business Administration \\ University of Lagos \\ Akoka - Yaba, Lagos, Nigeria \\ E-mail: dixonogbechi@yahoo.com \\ Sikuade Oladimeji Jagun \\ Sol Simon Investments \\ Lagos, Nigeria \\ E-mail: sjagun@yahoo.com
}

\begin{abstract}
In recent years, research has revealed the importance of Corporate Social Responsibility (CSR) and its significant impact on organizational performance. Also, scholars have recognized that consumers' attitudes and behaviors towards products and organizations are greatly influenced by organizational CSR programs and strategies. Consumers are generally recognized as one of the primary stakeholders of organizations in the marketing exchange process hence their perceptions of CSR are important since stakeholders' perceptions influence organizations' CSR practices. Given the vibrant nature of the service industry in Nigeria in general and telecommunication industry in particular, this study applied the Analytic Hierarchy Process (AHP) Model to determine consumers' perceptions of the CSR activities and strategy for organizations in the Nigerian Global System for Mobile (GSM) telecommunication industry. To achieve these aims, a sample of 600 consumers of the four major operators in the Nigerian GSM telecommunication industry (MTN/AIRTEL/GLO/ETISALAT) were drawn from tertiary institutions using the convenience sampling technique. The data obtained was analyzed using descriptive statistics and the Expert Choice software. Findings show that the CSR activities consumers feel organizations in the Nigerian GSM telecommunications industry should place high priority on are: Organizing or participating in public welfare activities, encouraging employee's voluntary welfare programs, Improving employee welfare (facilities and benefits), Active contribution of tax to government and Contribution to cultural and literacy programs.
\end{abstract}

Key Words: CSR strategy, CSR activities, Consumers' perception, Analytic Hierarchy Process Model, Nigerian GSM telecommunications industry.

\section{Introduction}

In order for organizations to survive in the competitive marketing environment, they need to note that their long term survival partly depend on their ability to confront social and environmental issues by being socially responsible (Collier \& Esteban, 2007). In recent years, research has revealed the

\footnotetext{
* Corresponding author
} 
importance of Corporate Social Responsibility (CSR) and its significant impact on organizational performance (Dixon-Ogbechi, Aiyeku, Haran and Jarutirasarn, 2011). The concept CSR has been defined in different ways by various scholars. For instance, Pitt (2012) defined CSR in terms of three distinct constructs: environmental CSR, external social CSR and internal social CSR. Environmental CSR encompassed any action undertaken in order to promote environmental sustainability; external social CSR dealt with initiatives aimed at addressing the needs of individuals and communities while internal social CSR dealt with the degree to which organizations address social asymmetries with regards to gender, race, sexual orientation and disability (Aguilera, Rupp, Williams \& Ganapathi, 2007; Orlitzky, Siegal \&Waldman, 2011; Pitt, 2012). Given this, our study is concerned with the aspect of external social CSR aimed at satisfying the consumers' needs and wants. Some scholars such as Swaen \& Chumpitaz (2008), Persais (2002) and Guchait, Anner and Wu (2012) viewed CSR as "obligations that companies have to integrate environmental and social parameters into their modus operandi and long-term development policies". To this effect, Robins (2005) and Málovicsa, Csigéné and Kraus (2008) opined that CSR is centered on the notion that the business sector should not only concentrated on profit-oriented commercial activities but also play a noneconomic role in society.

Given that research has shown that consumers have a favourable attitude towards companies that engage in CSR (Beckmann, 2012) and that corporate socially responsible activities can create emotional bonds between consumers and organizations' brands and products (Cristache, Micu, Micu, and Susanu, 2010), this study applied the AHP model to determine whether consumers have preference for certain CSR activities of organizations. This is of essence because knowledge of the relative importance of the factors that affect customers' decisions can assist in the optimal allocation of organizational resources and development of appropriate CSR strategies.

\subsection{Statement of Problem}

Scholars as well as practitioners have understood the potential benefits of CSR and its impact on consumers' purchase decisions (Swaen \& Chumpitaz, 2008). Also, according to Guchait, Anner and Wu (2012), research by various scholars have revealed the influence of customers' perceptions of CSR on their attitudes towards organizations and their products. Furthermore, scholars such as Berens, van Riel, \& van Bruggen (2005) and Sen \& Bhattacharya (2001) have recognized that consumers' attitudes and behaviors towards products and companies are greatly influenced by organizational CSR programs and strategies. Yet, Pitt (2012) and Guchait, Anner and Wu (2012) are of the opinion that most research on CSR focus on product-oriented organizations. Consumers are one of the primary stakeholders of organizations in the marketing exchange process (Pitt, 2012) hence their perceptions of CSR are important since stakeholders' perceptions influence organizations' CSR practices (Dawkins \& Ngunjiri, 2008). Yet, as opined by Beckmann (2012), the relationships between CSR activities and consumers-asstakeholders' perceptions, attitudes and behaviours is still under researched. Thus, this study seeks to add to the existing body of research by applying the AHP model to determine consumers' preference for certain CSR activities of organizations (Folkes \& Kamins, 1999; Hunt \& Vitell, 1992; and Pitt, 2012).

\subsection{Purpose of Study}

This study seeks to:

i. Investigate how consumers rank the CSR activities embarked upon by organizations in the Nigerian GSM telecommunications industry using the AHP model.

ii. Determine consumers' relative importance ranking of the CSR activities performed by organizations in the Nigerian GSM telecommunications industry.

iii. Determining the CSR Strategy for organizations in the Nigerian GSM telecommunications industry. 


\section{B. N.,Dixon-Ogbechi, S.O. Jagun/ Determine consumers' perceptions of CSR strategy for organizations}

\subsection{Research Questions}

i. How do consumers rank the CSR activities embarked upon by organizations in the

Nigerian GSM telecommunications industry using the AHP model?

ii. What is consumers' relative importance ranking of the CSR activities performed by organizations in the Nigerian GSM telecommunications industry?

iii. What is the CSR Strategy for organizations in the Nigerian GSM telecommunications industry?

\section{Literature Review}

Research by various scholars has shown that CSR has a significant impact on organization's economic and financial performance (Luo \& Bhattacharya, 2008) hence organizations are incorporating it in corporate management (Swaen \& Chumpitaz, 2008). Also, scholars such as Cristache, Micu, Micu, and Susanu, (2010) have identified the economic benefits of an organization's CSR to include greater market share, high turnover and increase in consumers trust and loyalty. Craig (2012) investigated the impact that CSR has on perceptions of the reliability of a company's products and concluded that organizations have a responsibility to more than just their shareholders. Smith, Read, and Lopez-Rodriguez (2010) studied Customer Perceptions of Corporate Social Responsibility and discovered that consumers may make inferences about an organization's CSR performance on the basis of very limited information. Stawiski, Deal, and Gentry (2010) in their study opined that CSR is believed to result into increased corporate profitability because it is linked with more favourable corporate evaluations, increased purchase behaviour, higher customer satisfaction and market value of a firm and improves both customers and employees' perceptions of the organization.

In the same vein, Ioannis, and George (2010) stated that in recent years, socially responsible firms are receiving more favourable recommendations compared to previous years thereby showing changing perception of the value placed on CSR strategies by analysts. They added that scholars such as Fombrun and Shanley (1990); Fombrun (2005) and Freeman, Harrison and Wicks (2007) are of the opinion that stakeholder management theories suggest that CSR strategies may lead to better performance by protecting and enhancing corporate reputation. Given the above benefits, scholars have conducted various studies on CSR. For instance, Guchait, Anner and Wu (2012) took a consumer perspective and examined how consumers react and make decisions based on their perceptions of service quality and CSR. Sora (2011) examined consumer perceptions towards corporations (using Motorola and Kellogg as case studies) and three corporate communication strategies among which is CSR. Ioannis, and George (2010) studied the Impact of Corporate Social Responsibility on Investment Recommendations. Groza, Pronschinske and Walker (2011) investigated Perceived Organizational Motives and Consumer Responses to Proactive and Reactive CSR while Kennedy, Ferrell, \& LeClair (2001) and Wessels (2003) investigated the influence of CSR on brand image and consumer trust.

In view of the fact that research by Guchait, Anner and Wu (2012) revealed that most CSR related studies had been done in product-based industry while ignoring the service sector (Kang, Lee, \& Huh, 2010), we therefore decided to add to the body of knowledge by focusing on the service sector. Since the 1990s, the stakeholder perspective has started gaining ground hence organizations need to be socially responsible to their stakeholders (Pinkston \& Carroll, 1994; Moir, 2001). Consumers are one of the primary stakeholders of organizations in the marketing exchange process (Pitt, 2012) hence their perceptions of CSR are important since stakeholders' perceptions influence organizations' CSR practices (Dawkins \& Ngunjiri, 2008). Given the vibrant nature of the service industry in Nigeria in general and telecommunication industry in particular, this study applied the AHP Model to determine consumers' perceptions of the CSR activities and strategy for organizations in the Nigerian Global System for Mobile (GSM) telecommunication industry. 


\subsection{Theoretical framework and model development}

This study was based on the AHP model developed by Saaty (1980). The AHP was adopted because it has been successfully applied to solve multi-criteria decision making problems (Saaty, 1980; 2000) and it is a simple, logical and quantitative approach to reach the best decision (Abdullah and Egbu, 2011). For instance, Mohammad, Amir, Amir, Abolfazl, Reza, Seyed, and Arezou ( 2011) used it in the supplier selection process, to determine suitable suppliers who are able to provide the buyer with the right quality products and/or services at the right price, at the right time and in the right quantities. Also, Schoenherr, Rao Tummala, and Harrison (2008) used the AHP to assess supply chain risks by evaluating the importance of each risk factor with a view of determining the best alternative. Thus, we used the AHP to determine how consumers rank the CSR activities embarked upon by organizations in the Nigerian GSM telecommunications industry with a view to using this knowledge to determine the CSR strategy for such organizations.

In order to adapt this study to this model we needed to identify the goal (Determine Customers' CSR Activity Ranking); the criteria (CSR activities of organizations) and the alternatives (the four GSM operators). A description of the AHP model is presented in the theoretical framework below.

\section{FIGURE 1: THE FOUR GSM OPERATORS AHP MODEL}

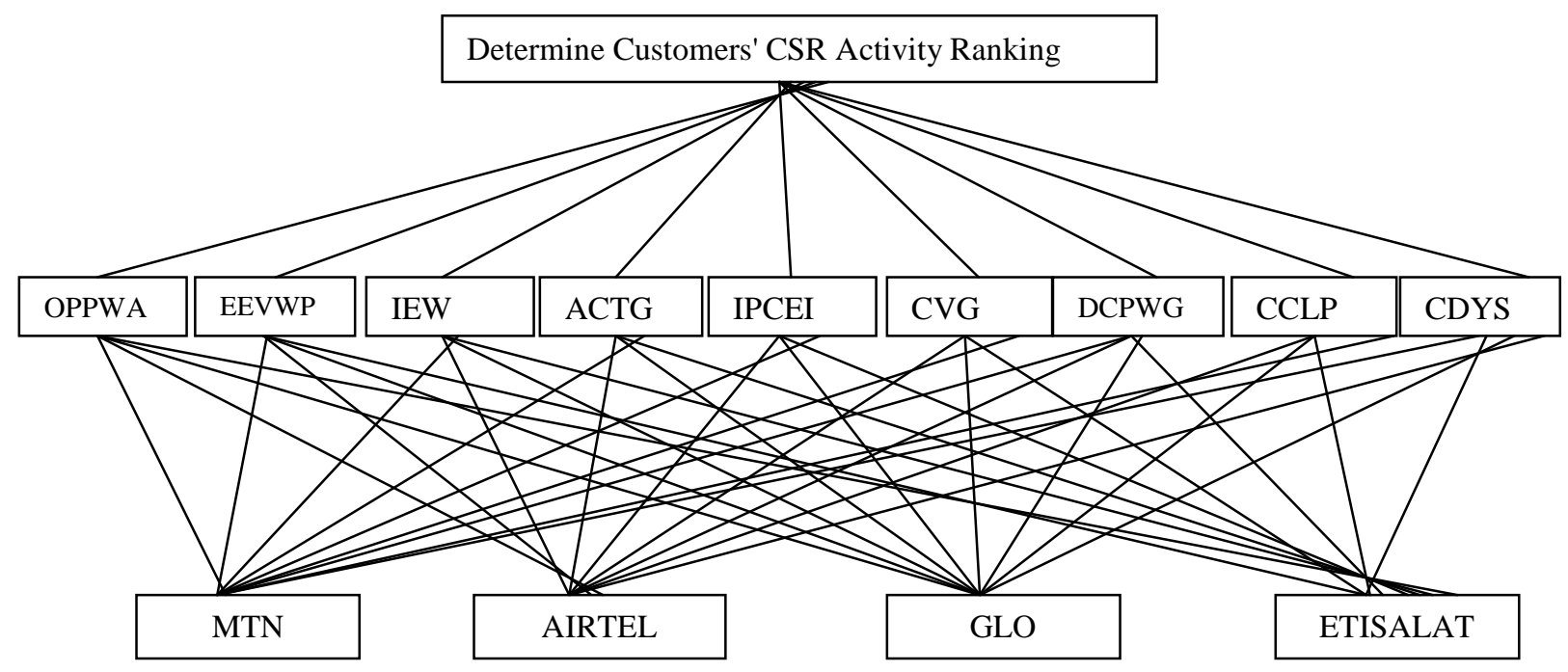

Source: Developed by the authors for this study

\subsection{Overview of the Nigerian Global System of Mobile Communication (GSM) Telecommunications Industry}

The Global System of Mobile Communication (GSM) was introduced into the Nigerian market following the globally lauded auction conducted by the Nigerian Communications Commission in January 2001. Then, three telecommunication organizations, namely, Econet (now Airtel), Mobile Telecommunication Network (MTN) and Communications Investments Limited (CIL) were registered and given the license to operate after satisfying the financial and other necessary requirements. However, while Econet was the first to be thus registered, MTN was the first to make a call on May 2001 thereby triggering what is today acclaimed to be one of the fastest growing GSM markets in the world. According to statistics from the Nigerian Communications Commission (NCC), compared with just about 450,000 working lines from Nigerian Telecommunication Agency (NITEL) in 2001, by August 2004, the GSM operators had recorded over seven million subscribers. In 2011, the figure had risen to over one hundred million. This colossal rise had been attributed to the massive expansion programmes launched by the operators (Jidaw Systems limited, 2012). 
MTN

MTN Nigeria is a part of the MTN Group, a South Africa based company which was licensed on February 9, 2001 as a GSM operator in Nigeria and on May 16, 2001, it became the first GSM network to make a call in Nigeria. As of February 10, 2003 MTN became the first mobile company to record one million active subscribers on its network and by June 30 2010, the subscribers base of MTN had risen to 35 million. MTN is a major operator in the Nigerian telecommunications industry that provides network coverage to $85.24 \%$ of Nigeria's land mass. MTN's has been a catalyst for Nigeria's economic growth and development especially through the MTN Foundation, through which it has been executing projects spanning the education, health and economic empowerment sectors in Nigeria. (MTN.NG.COM, 2012)

\begin{abstract}
AIRTEL
Airtel Nigeria (Airtel Networks Limited) is a member of the Airtel Africa Group. Econet (now Airtel) was the first to be licensed as a GSM operator in Nigeria in 2001 and made history on August 5, 2001 by becoming the first telecoms operator to launch commercial GSM services in Nigeria. The vision statement of Airtel is "being the most loved brand in the daily lives of Nigerians". In order to actualise this vision in the highly competitive Nigerian telecommunications market, AIRTEL was the first to: introduce toll-free 24-hour customer care, launch service in all the six geo-political zones in Nigeria, introduce affordable recharge denominations, introduce monthly free SMS and introduce monthly airtime bonus. In addition to these AIRTEL also offer a portfolio of innovative products and services ranging from exciting voice solutions to inventive data packages and mobile broadband to its consumers (AIRTEL Nigeria. 2013).
\end{abstract}

\title{
GLO
}

Globacom Limited is a telecommunications company and a member of the Mike Adenuga Group. GLOBACOM was launched in Nigeria in 2003, with the vision to be the telecommunications market leading service provider in Nigeria and also with a dream of building Africa's biggest and best telecommunications network. Glo Mobile, a subsidiary of GLO, is GLO's Mobile Network Unit which in the first year of operation, had one million subscribers in over 87 towns in Nigeria and over 120 billion Naira in revenues this has risen to over 25 million subscribers in a few years of operations (ITRealm, 2009; Wikipedia, 2012).

\section{ETISALAT}

The Emerging Markets Telecommunication Services (EMTS), trading as Etisalat, is a Nigerian company duly incorporated in January 2007 as a private company under the laws of Nigeria in partnership with Mubadala Development Company and Etisalat of the United Arab Emirates. In Nigeria, Etisalat made the first official call on its network on 13 March 2008 and in September of the same year, it kicked off commercial operations with the innovative '0809uchoose' campaign which enabled Nigerians choose numbers special to them as their mobile numbers. However, ETISALAT did not start Full commercial operations until October 2008. Even though it is the youngest in terms of introduction into the Nigerian GSM industry, as of 2011, the subscriber base of Etisalat Nigeria has grown to 15 million (UAE Interact. Com, 2012; Etisalat Nigeria (2013).

\section{Methodology}

\subsection{Research Design}

The exploratory research using the quantitative approach was used for this study.

\subsection{Population and Sample Size}

The population of this study is organizations in the Nigerian GSM telecommunication industry. A sample of the four major operators in this industry namely: MTN, GLO, Airtel and Etisalat were selected based on the judgmental sampling technique. On the other hand, convenience sampling technique was used to 
select a sample of 600 consumers of these four major operators from tertiary institutions other than universities namely: Lagos State Polytechnique, Yaba College of Technology, Lagos City Polytechnique and Federal College of Education in Lagos metropolis.

\subsection{Instrumentation}

In order to gather data, a self-completion questionnaire was designed by the authors. The questionnaire was divided into two sections. Section A was divided into two parts. Part I sought for demographic data of the respondents while part II sought for data about consumers' service provider; while Section B sought for data on relevant variables. Section A was designed using closed-ended, open-ended and multiple choice response structures; while section B was designed using the modified version of Saaty's scale of preference using relevant CSR variables identified in previous studies by Dixon-Ogbechi et al. (2011). Subsequently, the instrument was validated through content analysis and pilot study on a sample of 40 respondents.

\subsection{Data Analytical Procedure}

The data obtained in Section A was analyzed using descriptive statistics while section B was analyzed using the Expert Choice model.

\section{Results and Discussion}

\subsection{Response Rate}

Out of the 600 instruments administered, 508 were returned resulting in a response rate of $84.67 \%$. However, after the data editing process 387 (64.5\% ) questionnaires were correctly filled and used for this study.

\subsection{Demographics}

Findings reveal that $219(57 \%)$ of the respondents were male while $166(42 \%)$ were female. Three hundred and forty four (89\%) of them fell between 17 - 30 years of age; $271(70 \%)$ of them were full time students and 340 (88\%) of them spent (600-5,000 naira as monthly GSM phone bill). Also, 304 (79\%) of the respondents had contributed to a charitable cause at least once. The GSM service provider of 188 (49\%) was MTN, followed by $101(26 \%)$ was AIRTEL, $71(18.3 \%)$ was GLO and $46(11.9 \%)$ was ETISALAT while very few of them (04\%) used more than one provider. Almost all the respondents (371 i.e. $96 \%$ ) pay for their own GSM service and $308(80 \%)$ of them were on a prepayment plan.

\subsection{Consistency Index (CI)}

The consistency ratios of all the pair-wise comparison matrices were less than 0.1 , hence the judgments of the respondents were all seen to be consistent and therefore acceptable.

\subsection{Composite Priorities}

The priorities for the critical importance of the factors for the four organizations are as presented in the following table.

Table 1. Composite Priorities of the telecommunications companies CSR Activities

\begin{tabular}{|l|l|l|l|l|l|l|l|l|l|}
\hline CSR Activities & OPPWA & EEVWP & IEW & ACTG & IPCEI & CVG & DCPWG & CCLP & CDYS \\
\hline $\begin{array}{l}\text { Pooled Average } \\
\text { Composite Priority }\end{array}$ & 0.212 & 0.195 & 0.17 & 0.119 & 0.088 & 0.067 & 0.062 & 0.091 & 0.075 \\
\hline $\begin{array}{l}\text { Relative } \\
\begin{array}{l}\text { Importance } \\
\text { Ranking }\end{array}\end{array}$ & $\mathbf{1}$ & $\mathbf{2}$ & $\mathbf{3}$ & $\mathbf{4}$ & $\mathbf{6}$ & $\mathbf{8}$ & $\mathbf{9}$ & $\mathbf{5}$ & $\mathbf{7}$ \\
\hline
\end{tabular}

Source: Survey Research (2012) 
The table above shows that consumers believe that the important CSR activities organizations in the Nigerian GSM telecommunications industry should engage in are mostly Organizing or participating in public welfare activities (OPPWA) which had the highest rank closely followed by Encouraging employee's voluntary welfare programs (EEVWP) and Improving employee welfare (facilities and benefits) [IEW]. These were then followed by Active contribution of tax to government (ACTG); Contribution to cultural and literacy programs (CCLP); Improving pollution control / environment impact (IPCEI); Contribution to the development of youth and sport (CDYS); Contribution to vulnerable group $(\mathrm{CVG})$ and Donation to charitable and public welfare organizations (DCPWG) respectively.

Table 2. Composite Priorities of the telecommunications companies

\begin{tabular}{|l|c|c|}
\hline Companies & Pooled Average Composite Priority & Relative Importance Ranking \\
\hline MTN & 0.402 & 1 \\
\hline AIRTEL & 0.330 & 2 \\
\hline GLO & 0.168 & 3 \\
\hline ETISALAT & 0.100 & 4 \\
\hline
\end{tabular}

Source: Survey Research (2012)

Table 2 above reveals that MTN has the highest composite priority and ranking followed by AIRTEL, GLO and ETISALAT respectively.

\section{Conclusion and Recommendation}

The results of the AHP model showed consumers' perceptions of the CSR activities organizations in the Nigerian GSM telecommunications industry should engage in. Though nine different CSR activities were listed, a close look at the results revealed that consumers place a high priority on organizing or participating in public welfare activities (OPPWA), closely followed by encouraging employee's voluntary welfare programs (EEVWP), improving employee welfare (facilities and benefits) [IEW], active contribution of tax to government (ACTG) and by contribution to cultural and literacy programs (CCLP) whose combined priorities (0.787) are far more than those of the other CSR activities combined. The quantitative values (composite priorities) can be used as a percentage basis for budgetary allocation to the various activities. Results also showed the order in which consumers believe the organizations should engage in these CSR activities with MTN and AIRTEL having the highest combined priorities (0.732); this implies that these organizations may need to revisit their present CSR strategies in order to satisfy their consumers better. This is particularly important given that research has shown that organizations that participate in CSR will have more customers, face low business conflict and have more loyal employees (Dixon-Ogbechi et al., 2011).

Given this and the fact that organizations that hope to compete effectively need to take consumers' perceptions into cognizance we recommend that organizations in the Nigerian telecom industry should invest a larger part of their CSR budget to the above mentioned CSR activities as prioritized by consumers based on the AHP model.

\subsection{Further Studies}

This study used the AHP model to determine the CSR strategy for organizations in the Nigerian GSM telecommunications industry based on consumers' perceptions. Further studies can be conducted to investigate the socially responsible activities these organizations are actually investing in with a view of finding out whether their thinking is in line with consumers' thinking. 


\section{REFERENCES}

Abdullah, M R and Egbu, C (2011). The application of Analytic Hierarchy Process (AHP) as a decision tool in choosing the type of Industrialised Building System (IBS) for housing projects. In: Egbu, C and Lou, E C W (Eds.), Proceedings 27th Annual ARCOM Conference, 5-7 September 2011, Bristol, UK. Association of Researchers in Construction Management, 555-62.

Aguilera' Ruth V., Rupp, Deborah E., Williams, Cynthia A., \& Ganapathi, Jyoti (2007). Putting the S back in corporate social responsibility: A multilevel theory of social change in organizations". The Academy of Management Review, 32(3/July), 836-863.

AIRTEL Nigeria (2013). Airtel Nigeria's Overview. Retrieved February, 2013 from: Linkdin. http://ng.linkedin.com/pub/airtel-nigeria/54/a84/979.

Beckmann, Suzanne C. (2012). Consumers' perceptions of and responses to CSR: So little is known so far. Retrieved November 02, 2012 from: http:// www.kommunikationsforum.dk/file.asp?id=2100.

Berens, Van Riel, \& Van Bruggen (2005) In Guchait, Priyanko, Anner, Mark and Wu, Luorong (2012). Customer perceptions of corporate social responsibility of service firms: Impact on customer attitudes and behavioral intentions. Retrieved November, 20, 2012 from http://scholarworks.umass.edu/cgi/ viewcontent.cgi $?$ article $=1034$ \& context $=$ gradconf_hospitality\&sei-redir $=1 \&$ referer $=$.

Collier, J. \& Esteban, R. (2007). Corporate social responsibility and employee commitment. Business Ethics, a European Review, 16, 19-33.

Craig , Pearce (2012). "CSR Strategy Does make a PR Difference- New Finding". Retrieved November 12, 2012 from Public relations and managing reputation: http://craigpearce.info/public-relations/csrstrategy-pr-difference-finding/.

Cristache, Nicoleta., Micu, Adrian, Micu, Angela-Eliza and Susanu, Irina (2010). The analysis of the customers' perception on CSR - tridimensional approach - cultural, economical and social. The Annals of "Dunarea de Jos" University of Galati Fascicle I - 2010. Economics and Applied Informatics. Years XVI - no 1 - ISSN 1584-0409.

Dawkins, C. \& Nghunjiri, F. W. (2008). Corporate social responsibility reporting in South Africa: A descriptive and comparative analysis. Journal of Business Communications, 45, 286-307.

Dixon-Ogbechi, Bolajoko N., Aiyeku, Joseph F., Haran, Elizabeth \& Jarutirasarn, Piyachat (2011). "Marketers' perception of corporate social responsibility and the impact on company's performance: A study of companies in the nigerian service industry in lagos metropolis". Paper presented at the 2011 International Conference on CRS in Sub-Saharan Africa, December 12-14, Lagos, Nigeria.

Etisalat Nigeria (2013). About Etisalat Nigeria. Retrieved February 27, 2013 from: Linkedin: http://www.linkedin.com/company/etisalat-nigeria.

Folkes, V. S. \& Kamins, M. A. (1999). Effects of information about firms - ethical and unethical actions on consumer attitudes. Journal of Consumer Psychology, 8(3), 243-59.

Fombrun, C. \& Shanley, M. (1990). What's in a name? Reputation building and corporate strategy. Academy of management Journal, 233-258. 
Fombrun, C. 2005. Building corporate reputation through CSR initiatives: evolving standards. Corporate Reputation Review, 8(1): 7-11.

Freeman, R. E., Harrison, J. S., \& Wicks, A. C. 2007. Managing for stakeholders: survival, reputation, and success. New Haven, CT: Yale Univ Press.

Groza, D. Mark, Pronschinske R. Mya and Walker Matthew (2011). "Perceived organizational motives and consumer responses to proactive and reactive CSR". Journal of Business Ethics. 102, 639-652 _ Springer 2011 DOI 10.1007/s10551-011-0834-9.

Guchait, Priyanko, Anner, Mark and Wu, Luorong (2012). Customer perceptions of corporate social responsibility of service firms: Impact on customer attitudes and behavioral intentions. Retrieved November, 20, 2012 from: http://scholarworks.umass.edu/cgi/viewcontent.cgi?article $=1034$ \&context $=$ gradconf_hospitality\&sei-redir $=1 \&$ referer $=$.

Hunt, S. D. \& Vitell, S. J. (1992). The general theory of marketing ethics: a retrospective and revision. In: Smith, N. C. and Quelch, J. A. (Eds.), Ethics and Marketing, pp. 775-784. Homewood, IL: Irwin.

Ioannis Ioannou, George Serafeim (2010). The impact of corporate social responsibility on investment recommendations, Best Paper Proceedings, Academy of Management Social Issues in Management (SIM) Division).

ITRealm (2009). Glo May acquire NITEL". ITRealm. WEDNESDAY, SEPTEMBER 16, 2009. http://www.itrealms.com.ng/2009/09/glo-may-acquire-nitel.html.

Jidaw Systems limited (2012). GSM operators in Nigeria. Retrieved November 19, 2012 from: http://www.jidaw.com/telecom/gsm.html.

Kennedy, Ferrell, \& LeClair (2001). In Guchait, Priyanko, Anner, Mark and Wu, Luorong (2012). Customer perceptions of corporate social responsibility of service firms: Impact on customer attitudes and behavioral intentions. Retrieved November, 20, 2012 from http://scholarworks.umass.edu/cgi/ viewcontent.cgi $?$ article $=1034 \&$ context $=$ gradconf_hospitality \&sei-redir $=1 \&$ referer $=$.

Málovicsa, György, Csigéné, Noémi Nagypál, Kraus Sascha (2008). " The role of corporate social responsibility in strong sustainability". The Journal of Socio-Economics, 37, 907-918.

Mohammad Saeed Zaeri, Amir Sadeghi, Amir Naderi, Abolfazl Kalanaki, Reza Fasihy, Seyed Masoud Hosseini Shorshani, and Arezou Poyan (2011). "Application of multi criteria decision making technique to evaluation suppliers in supply chain management". African Journal of Mathematics and Computer Science Research, March , 4 (3), 100-106.

Moir, L. (2001). What do we mean by corporate social responsibility? Corporate Governance, 1, 16-22.

Orlitzky, M., Siegal, D. S., \& Waldman, D. A. (2011). Strategic corporate social responsibility and environmental sustainability. Business \& Society, 50, 6-27.

Persais (2002) in Guchait, Priyanko, Anner, Mark and Wu, Luorong (2012). Customer perceptions of corporate social responsibility of service firms: Impact on Customer attitudes and behavioral intentions. Retrieved November, 20, 2012 from http://scholarworks.umass.edu/cgi/viewcontent.cgi?

article $=1034 \&$ context $=$ gradconf_hospitality \&sei-redir $=1 \&$ referer $=$. 
Pinkston, T. S., \& Carroll, A. B. (1994). Corporate citizenship perspectives and foreign direct investment in the US. Journal of Business Ethics, 13 (2), 157-169.

Pitt, Bianca Agresti (2012). "Employee Perceptions of Social and Environmental Corporate Responsibility: The Relationship with Intention to Stay and Organisational Commitment". A research project submitted in partial fulfilment of the requirements for a Master of Arts degree, by coursework and research report, for Industrial Psychology in the Faculty of Humanities, University of the Witwatersrand, Johannesburg.

Robins, F., 2005. Why corporate social responsibility should be popularised but not imposed. In: Proceedings of the European Academy of Management Conference, 2005, Munich.

Saaty, Thomas L. (1980). The Analytical Hierarchy Process. New York: McGraw-Hill.

Saaty, Thomas L. (2000). Fundamentals of Decision Making and Priority Theory With Analytical Hierarchy Process. Pittsburgh, PA: RWS Publications.

Schoenherr, T., Rao Tummala, V.M., Harrison, T.P. (2008). "Assessing supply chain risks with the analytic hierarchy process: Providing decision support for the offshoring decision by a US manufacturing company". Journal of Purchasing and Supply Management. 14(2, June), 100-111.

Sen, S., \& Bhattacharya, C. B. (2001). Does doing good always lead to doing better? Consumer reactions to corporate social responsibility. Journal of Marketing Research, 38, 225-243.

Smith, N. Craig; Read, Daniel and Lopez-Rodriguez, Sofia (2010). Customer Perceptions of Corporate Social Responsibility: The CSR Halo Effect ( A working Paper in the INSTEAD Working Paper Series; Printed at INSTEAD, Fontainebleau, France.(2010/16/ISIC).

Sora, Kim (2011). Transferring Effects of CSR Strategy on Consumer Responses: The Synergistic Model of Corporate Communications Strategy. Journal of Public Relations Research, 2.

Stawiski, Sarah, Deal J. Jennifer, and Gentry, William (2010). "Employee Perceptions of Corporate Social Responsibility The Implications for Your Organization" - Center for Creative Leadership. () 2010 Center for Creative Leadership.

Swaen \& Chumpitaz (2008) in Guchait, Priyanko, Anner, Mark and Wu, Luorong (2012). Customer perceptions of corporate social responsibility of service firms: Impact on customer attitudes and behavioral intentions. Retrieved November, 20, 2012 from http://scholarworks.umass.edu/cgi/ viewcontent.cgi $?$ article $=1034 \&$ context $=$ gradconf_hospitality\&sei-redir $=1 \&$ referer $=$.

UAE Interact. Com (2012). Etisalat launches operation in Nigeria. Retrieved December 28, 2012 from: http://www.uaeinteract.com/docs/Etisalat_launches_operation_in_Nigeria/29150.htm

Wikipedia (2012). "Globacom". Wikipedia. http://en.wikipedia.org/wiki/Globacom£cite_note-5.

Wessels (2003) in Guchait, Priyanko, Anner, Mark and Wu, Luorong (2012). Customer Perceptions of Corporate Social Responsibility of Service Firms: Impact on Customer Attitudes and Behavioral Intentions. Retrieved November, 20, 2012 from http://scholarworks.umass.edu/cgi/viewcontent.cgi? article $=1034$ \& context $=$ gradconf_hospitality\&sei-redir $=1 \&$ referer $=$. 